\title{
長期透析患者の合併症とその対策
}

浅野 泰*

\begin{abstract}
要旨
慢性透析療法が一般化されて約20年上なるが，その間の技術的進歩や合併症対策の改善によ り、慢性維持透析患者数は年々増え続け，1990年にはかが国で10万人を超えた。しかしながら， 透析療法は腎の働きを完全に代償しているだけではないので，透析患者では多くの代謝異常や 合併症を伴い，そ机は全身に及ぶ、なかでも堅性貧血の存在は患者の社会活動や生活意欲の抑 制につながり，斗た循環器系合併症は透析患者の死因の過半数を占めるに至っている．最近， エリスロポエチンの臨床使用が可能となり，腎性貧血から透析患者を解放したが，副作用等委 だ十分に解明されていない点がある。一方，循環器系合併症の発生には腎不全むたは透析療法 に特有なるのがあり、こ饥らの原因追求，予防，治療名長期透析患者の予後にとって重要と考 えられる。
\end{abstract}

[日内会誌 $81 ： 1273 \sim 1278 ， 1992]$

Key words : hemodialysis, erythropoietin, cardiovascular complications

はじめに

慢性腎不全患者に対する長期血液透析療法は, 一般化されるようになって約20年となる。その間， 患者数は年々增加し，わが国での維持透析患者数 （腹膜透析患者数も含む）は，1990年には10万人を 超觉た。ま，10年以上の長期透析患者数も2万 人近くおり，この数も年々増加している。このこ とには，透析技術の進歩，機器の改良，合併症に 対する治療法の進歩などが大さく関係しているも のと思われる。

しかしながら現在の透析療法は，健常な腎藏の 機能をすべて代償することは不可能であり，生だ 多くの問題が残っている、合併症の多いこと劣て のためであり，※た，その合併症も全身に及び(表 1), 維持透析患者では全身管理が重要となってい

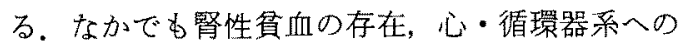
負担，二次性副甲状腺譏能元進症・アルミニウム 骨症・アミロイド骨症等による骨障害などは，患

*あさのやすし, 自治医科大学留藏内科
者の社会活動・行動範柬・生活意欲の抑制につな がり，いわゆるquality of life (QOL)の低下にな る.

一方，わが国の透析患者の死因調查(表 2)门

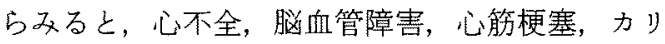
ウム中毒など循環器系合併症が過半数となってい る、したがって, 死因からみれば盾環器系合併症 の予防・治療が重要といえる。

本稿では透析患者の合併症の寸べてについて語 ることはできないので，最近特に注目されている 腎性預衈上死因第 1 位に位置する㡒環器系合併症 について述べることとする。

\section{1. 腎性責血の原因と対策}

腎性筫血の主たる原因が腎性エリスロポエチン 産生障害によることは周知の事実である。

血液中に造血因子が存在することは，ずでに 1900年代当初に述べられていたが，科学的にその 存在が証明されたのは1950年のReissmann'炕よ る.エリスロポェチン（EPO）と名付けられたこ の物筫保，その後，測定法の進歩，物質の同定・ 
表 1. 慢性透析患者の合併症

1、循環器系 (表 4)

2. 神経系

中枢神経障害, 末梢神経障害, 手根管症候群 ( ミミロイト沈着症)，尿毒症性脳症，精神異 常

3. 呼吸器系

胸水・胸膜炎，层䓯症性肺

4. 消化器系

口内炎，置・十二指腸潰福，出血性胃腸炎， 耳下腺资，膵资，展毒症性悪心・呕吐

5. 造血器系

坌血, 出血傾向

6. 内分泌采

副甲状腺機能元進症，甲状腺腫，甲状腺機能 低下症，女性化乳房・インポテンッ（男性）, 無月経・不妊（女性）

7. 脂質 - 代謝系 脂質代謝異常，糖代謝異常

8. 骨・骨代謝系

管軟化症，骨線雄症，骨折，烡所性石灰化， (アルミニウム骨症，アミロイド骨庭）

9. 水・電解罂, 酸塩基平衡障害

高 $\mathrm{K}$ 血症，低Ca血症，高リン血症，浮腫，脱 水など

10. 䑁覚器障害

眼：眼底出血，網膜剝離，red eye syndrome 皮膚：色素沈着，櫁洋症

表 2. 慢性透析患者の年間死亡原因（1990年）1

\begin{tabular}{|c|c|c|}
\hline & 人 数 & $\%$ \\
\hline 心不全 & 2558 & 30.4 \\
\hline 脳血管障害 & 1169 & 13.9 \\
\hline 感染症 & 976 & 11.6 \\
\hline 出血 & 294 & 3.5 \\
\hline 熏性睡瘍 & 689 & 8.2 \\
\hline 悪液質/尿毒症 & 471 & 5.6 \\
\hline 心筋梗塞 & 490 & 5.8 \\
\hline カリウム中毒/頓死 & 361 & 4.3 \\
\hline 慢性肝炎/肝硬変症 & 160 & 1.9 \\
\hline 脳症 & 35 & 0.4 \\
\hline 自殺/拒否 & 68 & 0.8 \\
\hline 腸閉塞 & 70 & 0.8 \\
\hline 胡血栓/柽塞 & 43 & 0.5 \\
\hline 災害死 & 60 & 0.7 \\
\hline その他 & 390 & 4.6 \\
\hline 不明 & 179 & 2.1 \\
\hline 記載無し & 399 & 4.7 \\
\hline 合 & 8412 & 100.0 \\
\hline
\end{tabular}

分離・純化が成され，1977年，Miyakeら 31は遂に 尿由来のEPOの純化に成功した。これをもとに， 1985年 $\mathrm{Jacobs}^{4}$ と $\mathrm{Lin}^{5} 5^{5}$ は全く独立して，同時に $\mathrm{EPO}$ 遗伝子のクローニングに成功した，そして 翌1986年には早くも製品化されて臨床試験が開始 され，1990年に虫，わが国でも一般使用が可能(薬 価収載〉となったものである。

ここで腎不全患者の貧血の改善効果といらめざ ましい実績をあげるに至ったが，異例のスピード の使用開始で，まだ多くの末解決の問題も残され ている.

\section{1）エリスポエチンの臨床効果}

Ht 23\%以下の安定した維持透析患者に血液透 析終了時毎回（週 3 回）エリスロポエチンを 1500 単位静脈内に投与したところ，図 1 に示したよう に約半数の患者が 4 週後にはHt $3 \%$ 以上の上昇 を示した。一方，低反応群 $(\mathrm{Ht}<3 \%)$ で3000単位 に増量すると，4週後には約 $25 \%$ にHt $3 \%$ 以上 上昇を認めた。こうして 6000 単位まで増量すると 有効例はさらに增え，計 $98 \%$ に貝血の改善を認め た。このようにEPOの䝷血改善効果は確実で，か つ用量依存性であった。

この時の結果から, 3000 単位週 3 回まで増量し ても効果の諗められない場合には，その原因を追 求するべきであることが考えられる。まず，低反 応や無効果の場合には，造血の基となる鉄欠之(血 清鉄フコェリチン值）を考慮しなければならない が，さらに表 3 に示したよらな諸因子が想定され る.

\section{2）有用性と专血改善の目標値}

上述のように透析患者の貧血は改善され，それ に伴い貧血による自覚症状は著明に好転し，QOL は向上する。

このときの負血改善の目標は，運動機能，心機 能7などを含めたQOLの点からは，正常値まで Ht を上げる必要はなく，30\%程度上一般的には考え られている。これは，後述する副作用の面からも 支持されていることである。しかし，年齢や合併 症によっては，この目標值も当然上下するはずの もので，個々の症例によって目標値を定めるべき ものと考えられる。 


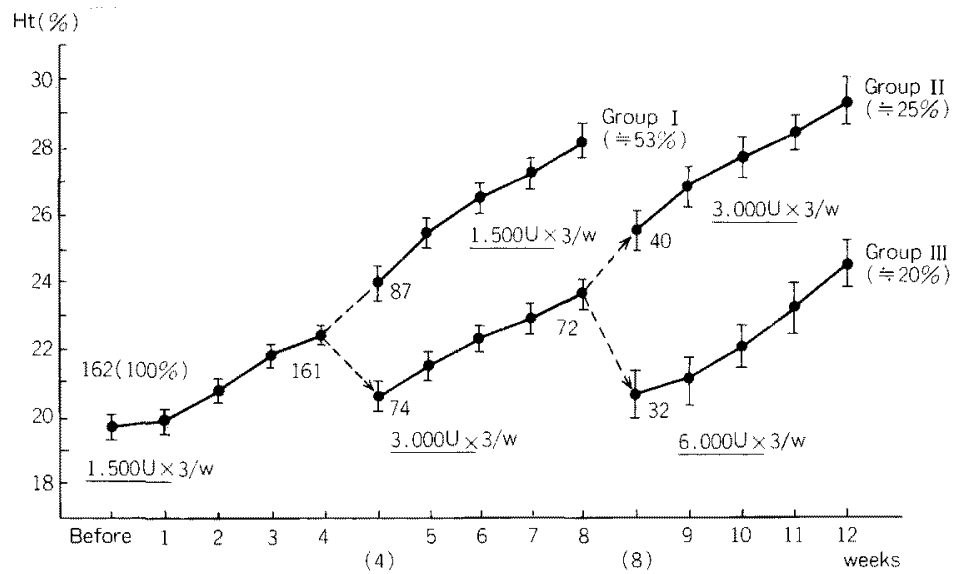

図 1. 透析患者に扔けるr-EPO投与量上造血反応

孯性貟血患者160例に1500単位週 3 回のEPOを投与し，4週後に反応群（Group I）で は，てのまま量を継続し，低反応群 (Group II) は，3000単位に增量して使用した。 以下同様に6000単位末で堌量した（多坆設協同研究報告による）6

表 3.エリス口ポエチンにより十分な造血反応が認め られない場合に考慮す心゙き病熊

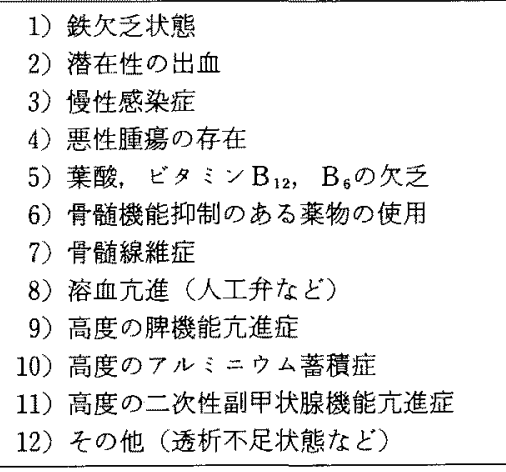

\section{3）副作用, 合併症と今後の問題点}

EPO自体に由来する副作用はほとんどなく，抗

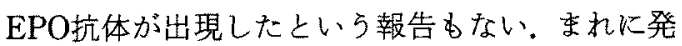
熱などのflu-like症状多がみられることがあるが， 急速静注でみられるようなので，慎重に投与すれ ば問題ないようである。

一方, 賓血改善に伴って, 高血王, 高血王脳症 (疰孪など), 血栓形成(脳梗塞, 心筋梗塞, シャ ント閉塞), 透析器内残血増加, 透析効率低下など の合併症がみられることがあるが，これらの合併 症は一般的に貫血改善速度の早いとき，過度の貧
血改善のときに起こしやすいとされているので， $\mathrm{H}$ tの改善速度や上昇目標値に注意する必要があ る.

しかし，高血圧の発症や頭重感などはHtが十分 に上昇しないらちから認められることがあり，必 ずしも $\mathrm{Ht}$ 上昇や血液粘度の上昇の夕で説明する ことはできない，最近，Heidenreichらッは，ラッ 卜腎血管や腸管膜動脈にてEPOが濃度依存性に 血管収縮を起こすことから，これがEPO投与によ る高血圧出現の原因であると報告した。乙かし， 比較的高濃度のEPOを使用していることなど，結 論に至るまでにはまだ問題がある。市た，EPO投 与後の透析患者の血中ノルェピネフリン濃度が上 界していること，アンギオテンシンI注入による 血管反応性が上界していること的なども高血王出 現の一因としての可能性が示唆されている.

\section{2. 循環器系合併症の現況と治療}

すでに述べたように慢性維持透析患者の合併症 は全身に及ぶが，死因からみた場合，循環器系合 併症が最も多い。

透析療法では末期腎不全患者を扱うこともあ り, 体液量の变動, 血清電解質や浸透俚の変動, 昇王・降厈物質の变動, 負血や自律神経機能異常 の存在,さらに血液透析ではンャントの存在, 透 
表 4. 慢珄透析患者の循環器合併症
1. 心機能障㕩
2. 心不全
3. 高血王
4. 低血王
5. 不整脈と洞機能不全
6. 心㷬炎
7. 虚血性心疾患
8. 動脈硬化
9. 这血管障害

析膜やアセテート透析液の使用などがあり，循環 器系合併症出現の要因や基となっている。そして 出来上った循環器合併症としては表 4 に示したよ らな病態があるが、これらのうち主なるのについ て最近の知見について解説寸る。

\section{1) 心機能障害}

透析患者の心機能の評価では高心拍状態がその 特徵である。その原因として，過鄱な体液の貯留， 筫血，高血左，内シャント，アシドーシスなどが あげられるが，これらが複合的に関与して成立す るものと考克られる。

この高心拍出状態の持続によると思われる所見 $に$, 非対称性心室中隔肥厚 (asymmetrical septal hypertrophy)がある。これは高血圧のない血液透

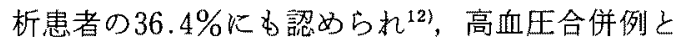
あわせるとかなり高率に譛められると思われる。

一方，覀毒症性心筫症之呼代れる病態があるが， これは長期透析患者で，さしたる冠動脈疾患や心 疾患の合研が無いのに心拍出量低下をきたして心 不全を呈するよらな状態を呼ぶ，原因の詳細は不 明であるが，高心拍出状態の長期持続もての一因 と考克られ，さらには図 2 に示したよらな心機能 に悪影響を及ぼす多くの因子が重って出現するも のと理解されている ${ }^{13}$.

2) 心不全

慢性透析患者の死因の $30 \%$ 前後と，全死因の第 1 位を占めている。全の定義では，心ポンプ 機能の破綻によって血液循環が不良となった状態 をいうのでするが，透析患者では心機能は正常に 保たれている（すくなくとも初期の段階では）に もかかわらず，腎障害のために体液の貯留がみら

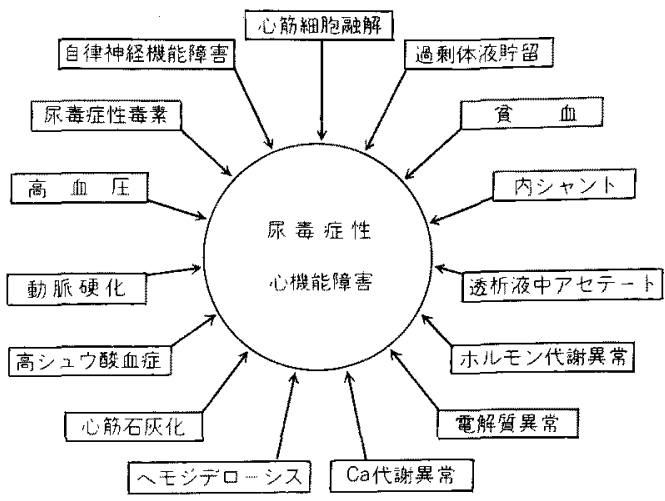

图2，尿毒定における心機能障害に関与する因子

れ，それで出現する心不全状態をいう。その意味 からは, 循環血液量増加による肺水腫といったほ らが適切かもしれない24).しかし，透析患者では上 述のように種々の心機能抑制因子る存在するの で，たんなる体液過鄱状態でかたずけられる問題 でもない.

いずれにしろ，体液過剩は透析患者心不全の主 因ではあるから，透析療法にて十分に体液を除去 しなければならない。この透析患者の体液過剩状 態を的確に把握する方法に乏しかったが，著者 $ら^{15)}$ は超音波断層法を用いて下大静脈径(IVC)を 測定し，これが透析患者の循環血液量と正相関す ることから, 体液量の評価, 透析に上る除水目標 量（いわゆるdry weight）設定に活用し，体液量 過剩の早期発見，心不全への進展抑止のための日 常的検查として用いている。

\section{3）不整脈}

透析患者に和ける不整脈発生頻度は一般人に比 较して高率である。これは，冠動脈疾患や心膜炎， 心筋症の合併の多いことが不整脈発生の基々なる のる一因であるが，これに加克て，透析㞠法によ る血行動態の変化, 代謝性アシドーシス・高K血 症・低K血症・高 $\mathrm{Mg}$ 血症・低Ca血症などの電解質・ 酸塩基平衡異常が増悪因子として働いている。 た，腎不全となる原因疾患をみれば，もともと刺 激伀導障害をきたしやすいつミロイドーシス，多 発性骨髄腫, 冠動脈硬化症の合併の多い糖氺病な どがあるのも一因と思われる。 
透析施行中にのみ出現したり，頻発したりする 不整脈もみられるが，この誘因としては，急速な 電解質の変化，血漿浸透圧の補正に上る細胞の内 外の平衡関俰の変化, 急速な除水に上る血行動態 の変化（血圧低下，循環障害，心筇虚血など）が 重要であると考えられる。

透析患者でみられる上室性期外収縮 (PAC) と 心室性期外収縮（PVC）の発生頻度は，一般健常 人より明らかに高率と思われるが，報告者により 差が認められる。その差は，対象となる透析患者 の原因疾患や年齢，透析歴などの違いによると思 われる、著者らの無作為抽出100例の維持透析患者 では, 88\%にPACが, 75\%にPVCが認められた ${ }^{16)}$. これらの治療の必要な例は18\%であったが，これ は諸家の報告による19－32\%と医淁一致してい る.

このときの結果では, PAC多発群ではPACのな い群に比べ, 高路であること, 非結合型Ca濃度の 上昇, 高遊離脂肪酸 $(\mathrm{FFA})$ 血症の存在, CTR(心 胸郭比) の增大，心ェコー上左房径の拉大などの 項目において有意差を認めた。一方，PVC多発群 での検討では，年齢，非結合型Ca濃度，FFA濃度 などでPACの場合と同じ傾向を認めた活か, Ca と リン積の増大, 心電図上QTc延長, 心エコー図で の\%FSの低下が特徴としてとらえられた。な透 析患者では心不全の合併が多く，それに対する digitalis使用で，中毒作用のために出現する不整 眽の多いことを留意しておかなければならない。

以上，透析患者で不整脈の多い理由として考克 られることを述べてきたが，最近，1例ではある が副甲状腺ホルモン（PTH）との関連に招いて興 味ある症例を経験した。詳細はすでに報告してい

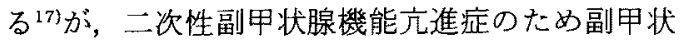
腺亚全摘術を目的として当科に入院してきた例で ある.本例では術前にPVCが多発していたのに, 術後全く消失してしまったことで, PTHを尿毒症 毒素と考学る向さからは大変興味する例であった といえる.

\section{4) 洞機能不全}

伝導障害である洞機能不全症候群 (SSS) も注目 されている病態である。そして，透析患者で認め
られるSSSのなかにも透析患者特有のるのが存在 すると思われる。すなわち，著者らが経験した徐 脈を示す 6 例の透析患者の5ち 3 例にSSSを認め たが，種々の検討から腎不全でないSSS患者では 認められない所見が発見された。

すなわち，透析患者では洞機能と血清 K值との 間に関連のあることが示され，His束心電図では， 血清K値の上犁に伴い，洞機能の指標であるSRT (sinus node recovery time) の著明な延長を示す 例があった ${ }^{18)}$.SRT延長の著明例では，血清K值が 一定值 $(4 \mathrm{mEq} / 10$ 例と， $5 \mathrm{mEq} / \mathrm{l}$ の例）を超える と洞性徐脈が出現し，それ以下では消失すること が確認されだ。このことは，正常の洞細胞では血 清K濃度とSRTとの間では相関々係はみられない ので，やはり，透析患者に特有な病態と考壳てよ いものと思われる。

\section{5）心膜炎}

透析患者にみられる心膜炎の多くは，尿毒症性 物質などによる化学的炎症反応によるものが多い と考克られている11). 臨床的には心膜液の貯留が 認められるが，心エコ一検查の導入から，透析患 者での心膜液貯留の頻度は意外と多いことが判明 した $(43 \%)^{19}$. 特に透析導入前㣦に多いが，炎症 の定義からして，すべてを心膜炎と呼ぶことはで きないが，その心膜液貯留の多少は，透析患者の 治療や予後を考える上で大切なことである。著者 ら ${ }^{191}$ は，心膜液貯留の程度と臨休所見とを比較検 討して, 心膜液大量貯留群ではHt值, 血清総蛋白, 血清アルブミン值の有意の低下，心胸比，左房径 の拡大など体液過剰を示唆する所見を認めた。 た，収縮期血厈の有意な高值を認め，高血圧また は昇王物質の関与を示唆する所見す得られた。

以上，心膜液貯留ない儿は心膜炎の予防や治療 には，栄羡状態や盆血の改善，体液過剩の是正の 必要なことが䂏える。

\section{文献}

1) 日本透析療法学会：かが国の慢性唀析潦法の現 況. 1990.

2) Reissman KR: Studies on the mechanism of erythropoietic stimulation in parabiotic rats during hypoxia. Blood 5: 372, 1950.

3) Miyake T, et al: Purification of human eryth- 
ropoietin. J Biol Chem 252: 5558, 1977.

4) Jacobs $K$, et al: Isolation and characterisation of genomic and cDNA clones of human erythropoietin. Nature $313: 806,1985$.

5) Lin F.K, et al: Cloning and expression of the human erythropoietin gene. Proc Natl Acad Sci USA $82: 7580,1985$.

6）平讯由平，他：腎性盆血患者飞対与る recombinant human erythropoietin (EPOCH)の臨床的 研究。腎之透析 $27: 157,1989$.

7) Macdougall IC, et al: Long-term cardiorespiratory effects of amelioration of renal anaemia by erythropoietin. Lancet 355:489, 1990.

8) Lasserre JJ, et al: A flu-like syndrome in patients treated with erythropoietin. Abs XXVth Cong of EDTA, Madrid, 1988.

9) Heidenreich $S$, et al: Direct vasopressor effect of recombinant human erythropoietin on renal resistance vessels. Kidney Intern $39: 259$, 1991.

10) Jandeleit $K$, et al: Increased activity of the autonomic nervous system and increased sensitivity to angiotensin II infusion after therapy with recombinant human erythropoietin. Nephron $56: 220,1990$.

11) 浅野 泰編著：透析療法の偱環器合併症. 中外医 学社, 東京, $1989, \mathrm{pl}$.
12) Bernardi $D$, et al: Asymmetrical septal hypertrophy in uremic-normotensive patients on reg. ular hemodialysis: An M-Mode and twodimension echocardiographic study. Nephron $39: 30,1985$.

13) 浅野泰, 安藤康宏: 偱環器系合併症と透析療法. 医学のあゆみ $159: 48,1991$.

14)浅野泰：析患者の浮腫。臨休唀析 1:87, 1985.

15）安藤康宏，他：超音波断㬝法に上る血液透析中の 下大静眽内径変化の柣討, 特に除水量との関係に ついて。，日本透析療法会誌 18: 173, 1985.

16) Kimura $K$, et al: Cardiac arrhythmias in hemodialysis patients: A study of incidence and contributory factors. Nephron 53: 201, 1989.

17) Kimura $\mathrm{K}$, et al: Ventricular tachyarrhythmia treated by parathyroidectomy in a chronically hemodialyzed patient. Nephron 53: 176, 1989.

18）中山䍩夫，他：慢性透析患者にお汁る血清カリウ 么值と洞機能一 3 症例老中心に. 臨床体夜 10 : 67, 1983.

19) Yoshida $K$, et al: Uremic pericardial effusion: Detection and evaluation of uremic pericardial effusion by echocardiography. Clin Nephrol 13:260, 1980. 